\title{
Preface: Introduction to the special issue "Connecting disciplines - Quaternary archives and geomorphological processes in a changing environment (proceedings of the Central European Conference on Geomorphology and Quaternary Sciences)"
}

\author{
Johanna Lomax, Thomas Kolb, and Markus Fuchs \\ Department of Geography, Justus Liebig University Giessen, Senckenbergstr. 1, 35390 Giessen, Germany \\ Correspondence: Johanna Lomax (johanna.lomax@geogr.uni-giessen.de) \\ Relevant dates: $\quad$ Published: 16 January 2020
}

How to cite: $\quad$ Lomax, J., Kolb, T., and Fuchs, M.: Preface: Introduction to the special issue "Connecting disciplines - Quaternary archives and geomorphological processes in a changing environment (proceedings of the Central European Conference on Geomorphology and Quaternary Sciences)", E\&G Quaternary Sci. J., 68, 241-242, https://doi.org/10.5194/egqsj-68-241-2020, 2020.

This special issue contains five scientific papers, which were presented at the "Central European Conference on Geomorphology and Quaternary Sciences", held in Giessen (Germany) in September 2018. The conference was organized by the German Association on Geomorphology (AKG - Deutscher Arbeitskreis für Geomorphologie) and the German Quaternary Association (DEUQUA - Deutsche Quartärvereinigung) and was hosted by the Department of Geography at the Justus Liebig University Giessen.

The aim of the conference was to bring together the closely related fields of geomorphology and Quaternary sciences under the guiding theme "Connecting Disciplines". The necessity of connecting the two disciplines arises from the fact that Quaternary deposits, accumulated thousands or hundred thousands of years ago, can only be understood if the geomorphological processes forming these deposits are known. Vice versa, today's geomorphological processes are often a reorganization of Quaternary (or older) sediments. Therefore, the Quaternary history of deposits and landforms needs to be considered when studying recent morphodynamics. Further sessions of the conference concentrated on geoarchaeology and on recent methodological advances.
Over 260 scientists from 19 different countries participated in the meeting, presenting cutting-edge research from both disciplines as keynote lectures, talks and posters. Student prizes for best oral presentations were awarded to Stefanie Tofelde (Potsdam) for her talk on "Effects of deepseated versus shallow hillslope processes on cosmogenic ${ }^{10}$ Be concentrations in fluvial sand and gravel" and to Anna Schoch (Bonn) for her talk on "Outsize fan evolution - internal structure and influence on the upper Rhone Valley, Switzerland". Two prizes for best poster presentations were handed over to Sebastian Kreutzer (Bordeaux) for his poster on "The Mousterian Loess Sequence La Combette (France): Chronological Evidence of Rapid Environmental Changes in the MIS 4/3 Transition" and to Janek Walk (Aachen) for his poster on "The Guanillos fan complex - implications for the morphogenesis of Atacama's coastal alluvial fans".

Following the guiding theme of the conference, this special issue assembles papers from geomorphology, Quaternary sciences and geoarchaeology. Von Scheffer et al. (2019) reconstruct palaeoenvironmental change and human impact recorded in the Kleinwalser Valley (northern Central Alps, Austria), using X-ray fluorescence (XRF), pollen analysis, 
and radiocarbon chronologies. They identify the first anthropogenic impact at around 5700 to $6300 \mathrm{BP}$, large-scale deforestation during the mid to late Bronze Age, and the arrival of the Walser people after around 1300 CE. Tinapp et al. (2019) investigate sediments from the lower Pleiße river in Saxony (Germany) using archaeological finds, plant remains, micromorphological and geochemical analysis and radiocarbon dating. They detect a prominent mid-Holocene black clay horizon, underlain by a sedge peat of Boreal and Preboreal age, as well as Weichselian sands. From 400 BCE onwards, overbank fines dominate, testifying land clearance activities, which intensified further during the Middle Ages. Marr et al. (2019) present ${ }^{10} \mathrm{Be}$ surface exposure ages of bedrock and boulder samples from southern Norway. These ages indicate an onset of deglaciation of the Scandinavian ice sheet at around $13 \mathrm{ka}$ in southwestern Norway. The paper of Schellmann et al. (2019) focusses on electron spin resonance (ESR) dating of small gastropod shells in order to establish a chronology of Pleistocene gravel terraces from valleys in the Bavarian Alpine Foreland. Their results match the stratigraphy very well and agree well with luminescence ages where available, showing the high potential of ESR dating for constraining the age of Pleistocene fluvial deposits. Dietze and Dietze (2019) use end-member modelling analysis (EMMA) of grain size distributions in order to decipher grain size populations and infer sedimentary histories. They provide R protocols for a robust EMMA and present tests of their model on a synthetic data set of natural sediment types such as loess, dunes and floodplain deposits.

\section{References}

Dietze, E. and Dietze, M.: Grain-size distribution unmixing using the R package EMMAgeo, E\&G Quaternary Sci. J., 68, 29-46, https://doi.org/10.5194/egqsj-68-29-2019, 2019.

Marr, P., Winkler, S., Binnie, S. A., and Löffler, J.: ${ }^{10}$ Be-based exploration of the timing of deglaciation in two selected areas of southern Norway, E\&G Quaternary Sci. J., 68, 165-176, https://doi.org/10.5194/egqsj-68-165-2019, 2019.

Schellmann, G., Schielein, P., Rähle, W., and Burow, C.: The formation of Middle and Upper Pleistocene terraces (Übergangsterrassen and Hochterrassen) in the Bavarian Alpine Foreland - new numeric dating results (ESR, OSL, 14C) and gastropod fauna analysis, E\&G Quaternary Sci. J., 68, 141-164, https://doi.org/10.5194/egqsj-68-141-2019, 2019.

Tinapp, C., Heinrich, S., Herbig, C., Schneider, B., Stäuble, H., Miera, J., and von Suchodoletz, H.: Holocene floodplain evolution in a central European loess landscape - geoarchaeological investigations of the lower Pleiße valley in NW Saxony, E\&G Quaternary Sci. J., 68, 95-105, https://doi.org/10.5194/egqsj-6895-2019, 2019.

von Scheffer, C., Lange, A., De Vleeschouwer, F., Schrautzer, J., and Unkel, I.: 6200 years of human activities and environmental change in the northern central Alps, E\&G Quaternary Sci. J., 68, 13-28, https://doi.org/10.5194/egqsj-68-13-2019, 2019. 